Original Research Paper

\title{
Geometric-Cinematic Synthesis of Planetary Mechanisms
}

\author{
${ }^{1}$ Nicolae Petrescu and ${ }^{2}$ Florian Ion Tiberiu Petrescu \\ ${ }^{1}$ Bucharest University, Bucharest, (CE), Romania \\ ${ }^{2}$ ARoTMM-IFToMM, Bucharest Polytechnic University, Bucharest, (CE), Romania
}

Article history

Received: 16-08-2018

Revised: 19-08-2018

Accepted: 27-08-2018

Corresponding Author: Florian Ion Tiberiu Petrescu ARoTMM-IFToMM, Bucharest Polytechnic University, Bucharest, (CE), Romania Email: scipub02@gmail.com

\begin{abstract}
The simple planetary mechanism is geometrically synthesized by determining the four tooth numbers of the component wheels. There are four main conditions that if not obeyed the mechanism will be blocked, will work with interruptions, or will not work at all. (a) The first condition in the geometric-kinematic synthesis of a simple planetary is the uniform loading of satellites (satellite groups) (or the simultaneous engagement condition). (b) The coaxiality condition is the second one to be observed, otherwise, the mechanism is inoperative. (c) The condition for achieving a required input-output transmission ratio is the third major condition, which results from the necessity of conceiving the mechanism according to the required operation. (d) The fourth imposed condition is that of (good) neighboring (of the satellite groups), which is necessary for the larger satellites belonging to two groups of neighboring satellites not to be touched, which is why it is necessary to introduce the additional condition, neighborhood.
\end{abstract}

Keywords: Automatic Gearboxes, Dynamic Synthesis, Simple Planetary Mechanism, Synthesis of a Planetary Mechanism

\section{Introduction}

Today the planetary mechanisms have spread to the machine building industry, especially in robotics, mechatronics, automation, aerospace, automobiles, etc. becoming more and more important so that a good design of them is more than necessary, otherwise there is a danger that they do not work properly, operate with interruptions, shocks, noise and vibration, beatings, blocking, or even break.

Manual gearboxes are increasingly being replaced by automatic or variable transmissions that make a better transition from one gear to another or even a permanent adaptation of the transmission to the demands of the road, so that fuel consumption can drop even by half, the noxes are also significantly reduced, so the noise and vibrations during the operation will be almost eliminated, drivers having the tendency to purchase such cars, which will make their life more enjoyable when they will be driving. In all these situations mechanisms are used which have one or more planetary mechanisms in their composition.

Automatic gearbox and transmission mode transmission mode in an automatic gearbox with planetary gears. The automatic gearbox (s) under study is 4HP20 from the ZF (Fig. 1).
The 4HP20 automatic gearbox has 4 transmission ratios (gears) and a maximum torque of $330 \mathrm{Nm}$. It consists of 2 simple planetary mechanisms, a blocking hydro transformer (clutch), two clutches, three multidrive brakes and an electrohydraulic control module.

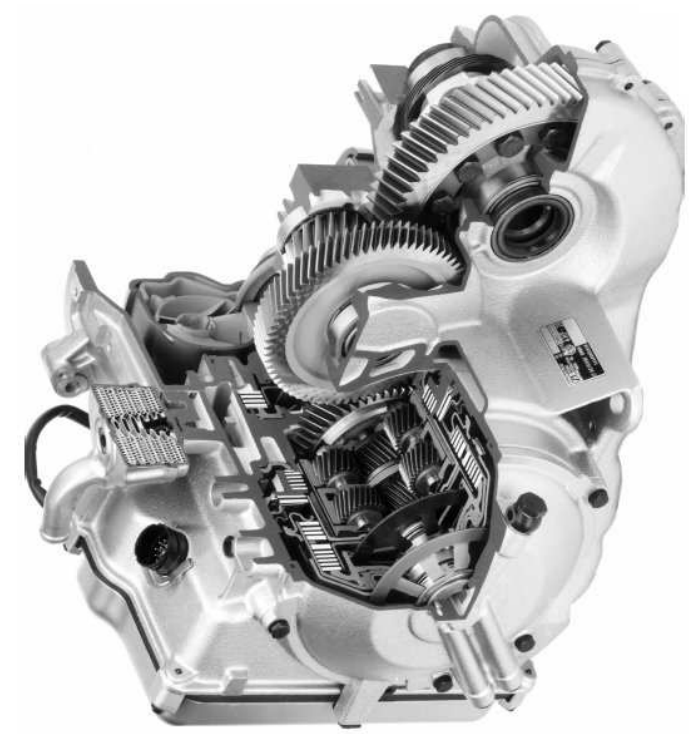

Fig. 1: The automatic gearbox $4 \mathrm{HP} 20$ from the $\mathrm{ZF}$ 
The 4HP20 is older generation but the same gearing principle applies to 8-speed or 9-speed automatic gearboxes. This box was used on a wide range of cars: Mercedes Benz, Renault, Peugeot, Fiat, Lancia, etc.

Currently, manufacturers such as Renault or PSA (Peugeot-Citroen) are selling cars that use derivative gears on this market in Turkey, Russia, Mexico, China, etc. The Dacia Duster with an automatic gearbox, marketed on the Russian market, has a gearbox similar to 4HP20 (see its components in the Fig. 2).
1. Radiator (cools the transmission oil)

2. Multidisc clutch

3. Multidisc brake

4. Reducer (final gear)

5. Differential

6. Hydrotransformer (torque converter)

7. Multifunctional contact

8. Ventilation valve

9. Lectrohydraulic control unit housing 10. Joja transmission oil
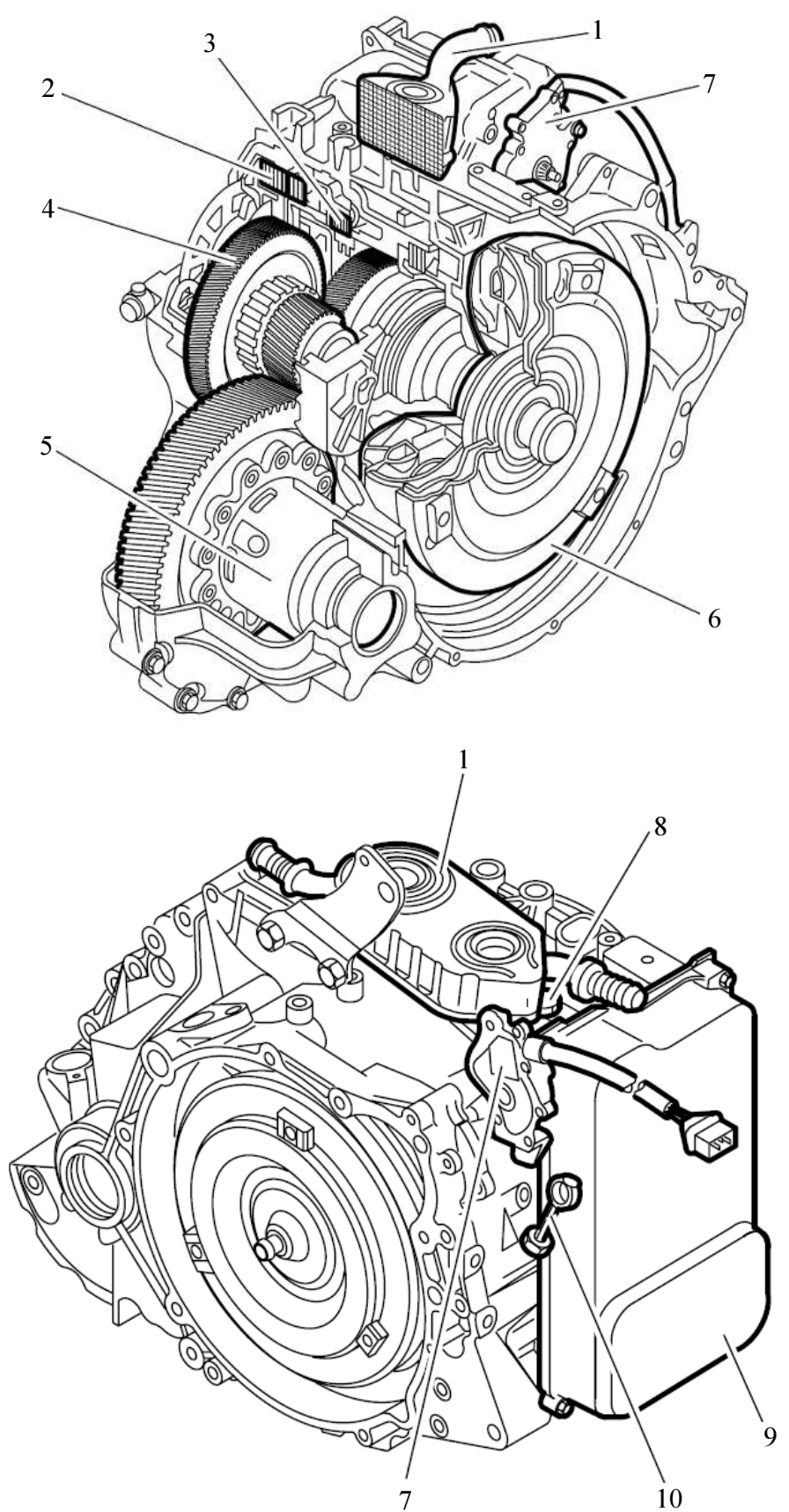

Fig. 2: Components of automatic gearbox $4 \mathrm{HP} 20$ 
The hydraulic transformer (torque converter) is equipped with a clutch controlled by an electric control valve. Typically, in gears 2,3 and 4, depending on the operating mode, the transmission computer controls the blocking of the hydrostatic to eliminate hydraulic losses.

The hydraulic circuit is also equipped with a cooling radiator. Because of the fact that it passes through the clutch discs and brakes, the oil can be heated very heavily, reaching temperatures above $100^{\circ} \mathrm{C}$. Under these circumstances, the transmission computer controls an electric valve that opens the cooling circuit and allows the oil to pass through the radiator (see the Automatic transmission 4HP20 cross section in the Fig. 3).

In the Fig. 3 one can see all the components from the cross section of the automatic transmission:
1. Clutch clutch hydrotransformer (torque converter)

2. Turbine

3. Pump

4. Input shaft

5. Free wheel

6. Stator

7. Oil pump

8. Toothed gear drive fixed gear

9. Output shaft speed sensor

10. Simple planetary mechanism 1

11. Simple planetary mechanism 2

12. Input shaft speed sensor

13. Fixed gear reducer intermediate gear

14. Toothed gear reducer

15. Differential crown

16. Crown feed oil clutch

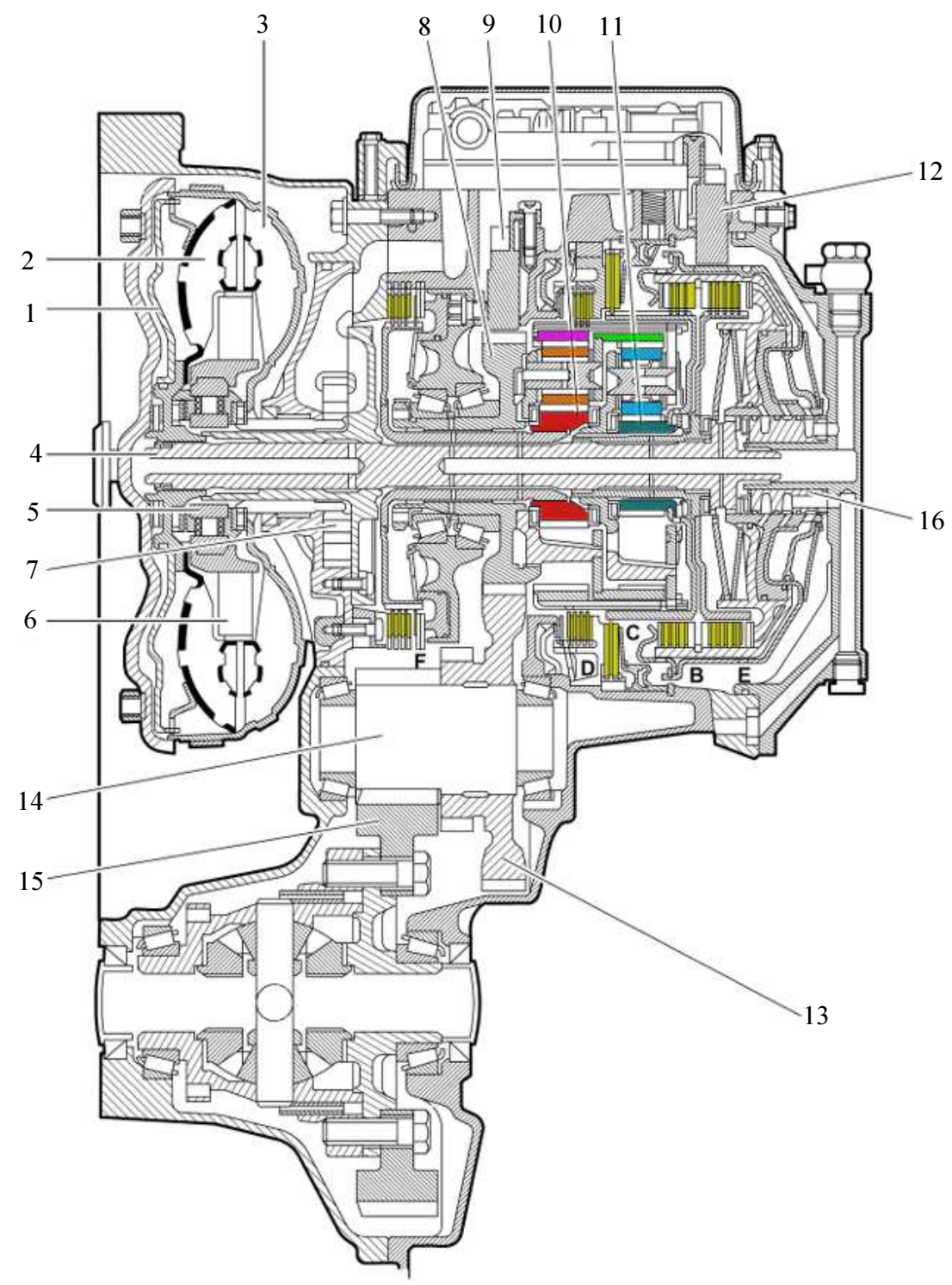

Fig. 3: Automatic transmission 4HP20 - cross section 


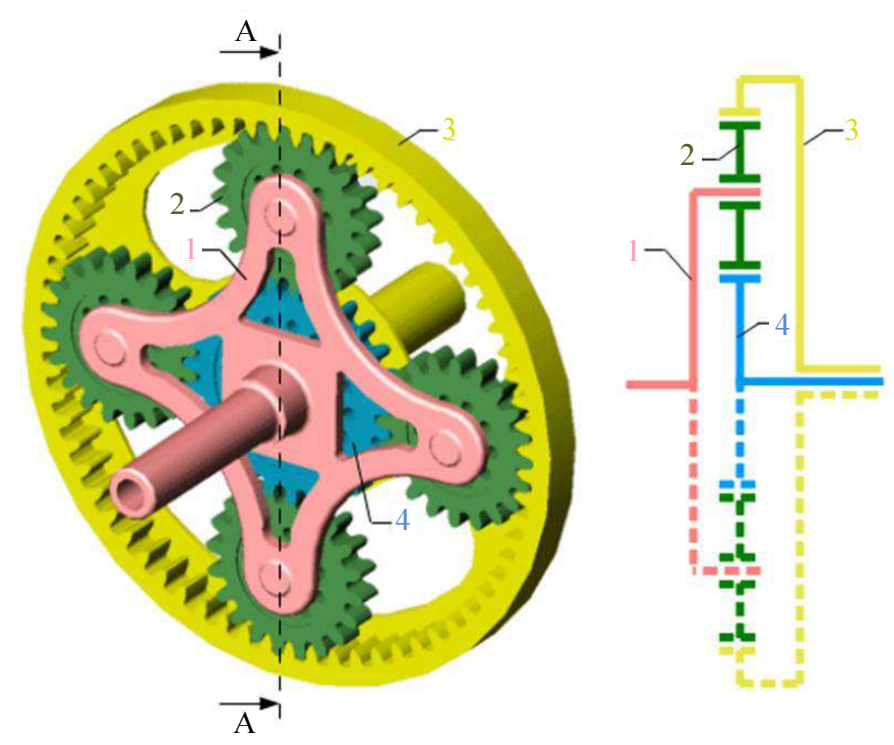

Fig. 4: Planetary mechanisms

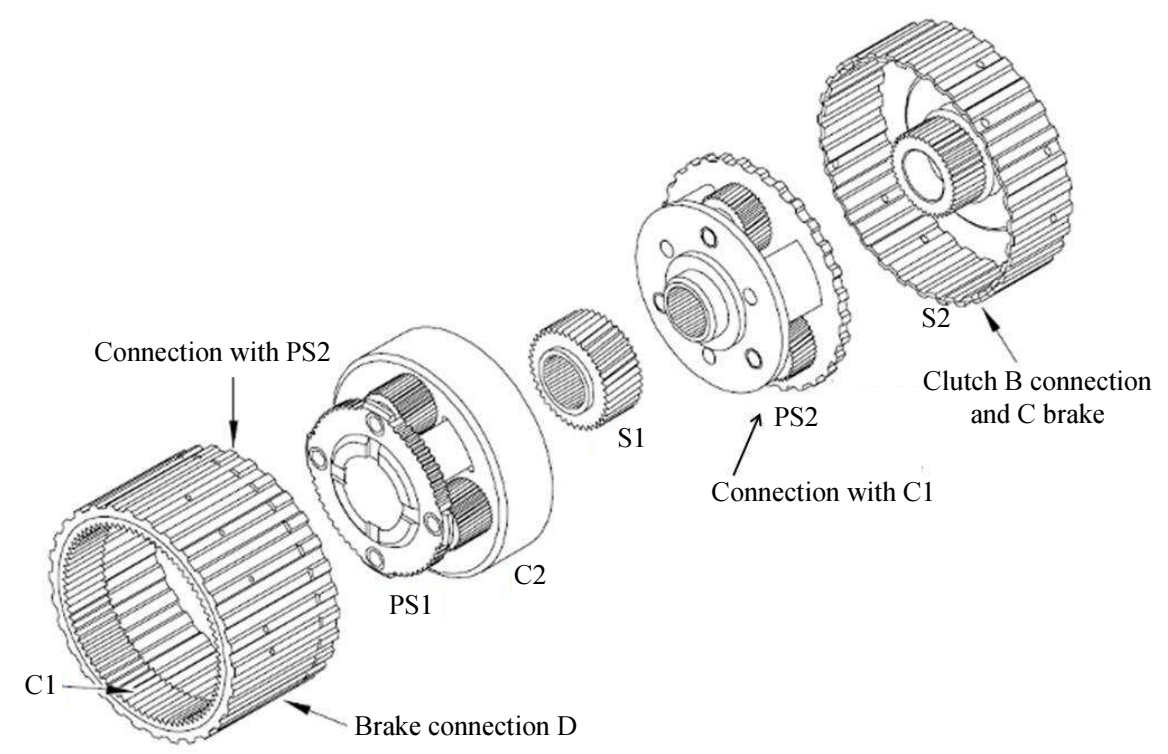

Fig. 5: Combining two simple planetary mechanisms, one can get 4 forward and one reverse track

\begin{abstract}
C1 - planetary gear crown 1
PS1 - planetary harbor plate harbor 1

S1 - solar planetary mechanism 1

C2 - planetary mechanism crown 2

PS2 - planetary gear port 2 satellites

S2 - solar planetary mechanism 2
\end{abstract}

Planetary mechanisms (Fig. 4) are simple, of the Simpson type. The ratio of each step is formed by planetary mechanisms plus a fixed reducer. To understand how gears are formed, we need to detail how a simple planetary mechanism works. A planetary mechanism consists of 4 elements:

1. Solar
2. Satellites

3. Port-satellite platform

4. The crown

The advantage of a simple planetary mechanism, compared to a gear with gears commonly used in manual gearboxes, is that it can provide several transmission ratios. Practically from a simple planetary 
mechanism, you can get 4 transmission reports and theoretically as many speeds.

A simple planetary mechanism consists of 3 gears: the sun, the satellites and the crown. By blocking an element and using the other two as input and output, several gears can be obtained.

If the crown sun is rigid, using a multidisc clutch, the entire mechanism will rotate unitarily, the transmission ratio, in this case, will be 1,000 (direct socket).

Obviously, not all transmission reports are directly usable. In other words, a single planetary mechanism is not enough to achieve the gear shifting of an automatic transmission. However, by combining two simple planetary mechanisms, you can get 4 forward and one reverse track (Fig. 5).

Frățilă et al. (2011; Pelecudi, 1967; Antonescu, 2000; Comănescu et al., 2010; Aversa et al., 2016a; 2016b; 2016c; 2016d; 2017a; 2017b; 2017c; 2017d; 2017e; Mirsayar et al., 2017; Cao et al., 2013; Dong et al., 2013; De Melo et al., 2012; Garcia et al., 2007; Garcia-Murillo et al., 2013; He et al., 2013; Lee, 2013; Lin et al., 2013; Liu et al., 2013; Padula and Perdereau, 2013; Perumaal and Jawahar, 2013; Petrescu and Petrescu, 1995a; $1995 \mathrm{~b} ; 1997 \mathrm{a} ; 1997 \mathrm{~b}$; 1997c; 2000a; 2000b; 2002a; $2002 \mathrm{~b} ; 2003$; 2005a; 2005b; 2005c; 2005d; 2005e, 2016a; 2016b; 2016c; 2016d; 2016e; 2013; 2012a; 2012b; 2011; Petrescu et al., 2009; 2016a; 2016b; 2016c; 2016d; 2016e; 2017a; 2017b; 2017c; 2017d; $2017 \mathrm{e} ; 2017 \mathrm{f} ; 2017 \mathrm{~g} ; 2017 \mathrm{~h} ; 2017 \mathrm{i} ; 2017 \mathrm{j} ; 2017 \mathrm{k}$; 2017l; 2017m; 2017n; 2017o; 2017p; 2017q; 2017r; $2017 \mathrm{~s} ; 2017 \mathrm{t} ; 2017 \mathrm{u} ; 2017 \mathrm{v} ; 2017 \mathrm{w} ; 2017 \mathrm{x} ; 2017 \mathrm{y}$; 2017z; 2017aa; 2017ab; 2017ac; 2017ad; 2017ae; Petrescu and Calautit, 2016a; 2016b; Reddy et al., 2012; Tabaković et al., 2013; Tang et al., 2013; Tong et al., 2013; Wang et al., 2013; Wen et al., 2012; Antonescu and Petrescu, 1985; 1989; Antonescu et al., 1985a; 1985b; 1986; 1987; 1988; 1994; 1997; 2000a; 2000b; 2001; List the first flights, From Wikipedia; Chen and Patton, 1999; Fernandez et al., 2005; Fonod et al., 2015; Lu et al., 2015; 2016; Murray et al., 2010; Palumbo et al., 2012; Patre and Joshi, 2011; Sevil and Dogan, 2015; Sun and Joshi, 2009; Crickmore, 1997; Donald, 2003; Goodall, 2003; Graham, 2002; Jenkins, 2001; Landis and Dennis, 2005; Clément, Wikipedia; Cayley, Wikipedia; Coandă, Wikipedia; Gunston, 2010; Laming, 2000; Norris, 2010; Goddard, 1916; Kaufman, 1959; Oberth, 1955; Cataldo, 2006; Gruener, 2006; Sherson et al., 2006; Williams, 1995; Venkataraman, 1992; Oppenheimer and Volkoff, 1939; Michell, 1784; Droste, 1915; Finkelstein, 1958; Gorder, 2015; Hewish, 1970).

\section{Materials and Methods}

The simple planetary mechanism (Fig. 6) is geometrically synthesized by determining the four tooth numbers of the component wheels. Four conditions are required.

(a) The first condition in the geometric-kinematic synthesis of a simple planetary is the uniform loading of satellites (satellite groups) (or the simultaneous engagement condition).

In order for the satellite groups to be uniformly charged (thus resulting in uniform and minimal wear with a quiet, long-running, no noise, vibration, shocks), the simultaneous engagement must take place, the satellites being symmetrically disposed at equal distances. It's obviously the satellite groups; if a single group of satellites was used, the loading would be large and especially uneven, with dynamic operation almost impossible because dynamic balancing could not be achieved. For this reason two, three, four, five, etc., satellite groups are used. A very good balance not only static but also dynamic is achieved, for example, when using at least three satellite groups.

If we calibrate the first group of satellites (vertically Fig. 6) so that the diameter $a_{1} a_{1}$ is an axis of symmetry, in the satellite group the two axes can no longer be positioned generally after the direction $a_{2} a_{2}$ ' but will be disengaged rotated at any angle $\alpha$ ) occupying the position $a a^{\prime}$. The disbanded positioning of the satellite 2 with the $a_{2} a$ segment must still fall into a number of steps: $a_{2} a=n_{1} . p_{1}$; the same phenomenon occurs at wheel $2^{\prime}: b_{2} b=n_{2} . p_{2}$; but also to the center wheel 1: $a_{1} c=n_{3} . p_{1}$; and the center wheel 3: $b_{1} d=n_{4} \cdot p_{2}$; as the process occurs without slipping, the segment $a_{2} a$ on the satellite wheel 2 must be equal to the segment $a_{2} c$ on the center wheel 1 . In addition $a_{1} a_{2}=z_{1}$. $p_{1} / k$; the relationship 1 follows:

$\left\{\begin{array}{l}a_{1} a_{2}=a_{1} c-a_{2} c=a_{1} c-a_{2} a=n_{3} \cdot p_{1}-n_{1} \cdot p_{1} \\ a_{1} a_{2}=\frac{z_{1} \cdot p_{1}}{k}\end{array} \Rightarrow z_{1}=k \cdot\left(n_{3}-n_{1}\right)\right.$

The relationship 2 is also determined:

$\left\{\begin{array}{l}b_{1} b_{2}=b_{1} d-b_{2} d=b_{1} d-b_{2} b=n_{4} \cdot p_{2}-n_{2} \cdot p_{2} \\ b_{1} b_{2}=\frac{z_{3} \cdot p_{2}}{k}\end{array} \Rightarrow z_{3}=k \cdot\left(n_{4}-n_{2}\right)\right.$

Four relationships can be written immediately (system 3), from which the four simultaneous engagement conditions can be concluded: $z_{1}, z_{3}, z_{3}-z_{1}, z_{1}$ $+z_{3}$, all four must be natural numbers, plus multiples of $k$ :

$\left\{\begin{array}{l}z_{1}=k \cdot\left(n_{3}-n_{1}\right)=k \cdot N_{1} \\ z_{3}=k \cdot\left(n_{4}-n_{2}\right)=k \cdot N_{2} \\ z_{3}-z_{1}=k \cdot\left(n_{1}+n_{4}-n_{2}-n_{3}\right)=k \cdot N_{3} \\ z_{3}+z_{1}=k \cdot\left(n_{3}+n_{4}-n_{1}-n_{2}\right)=k \cdot N_{4}\end{array}\right.$ 


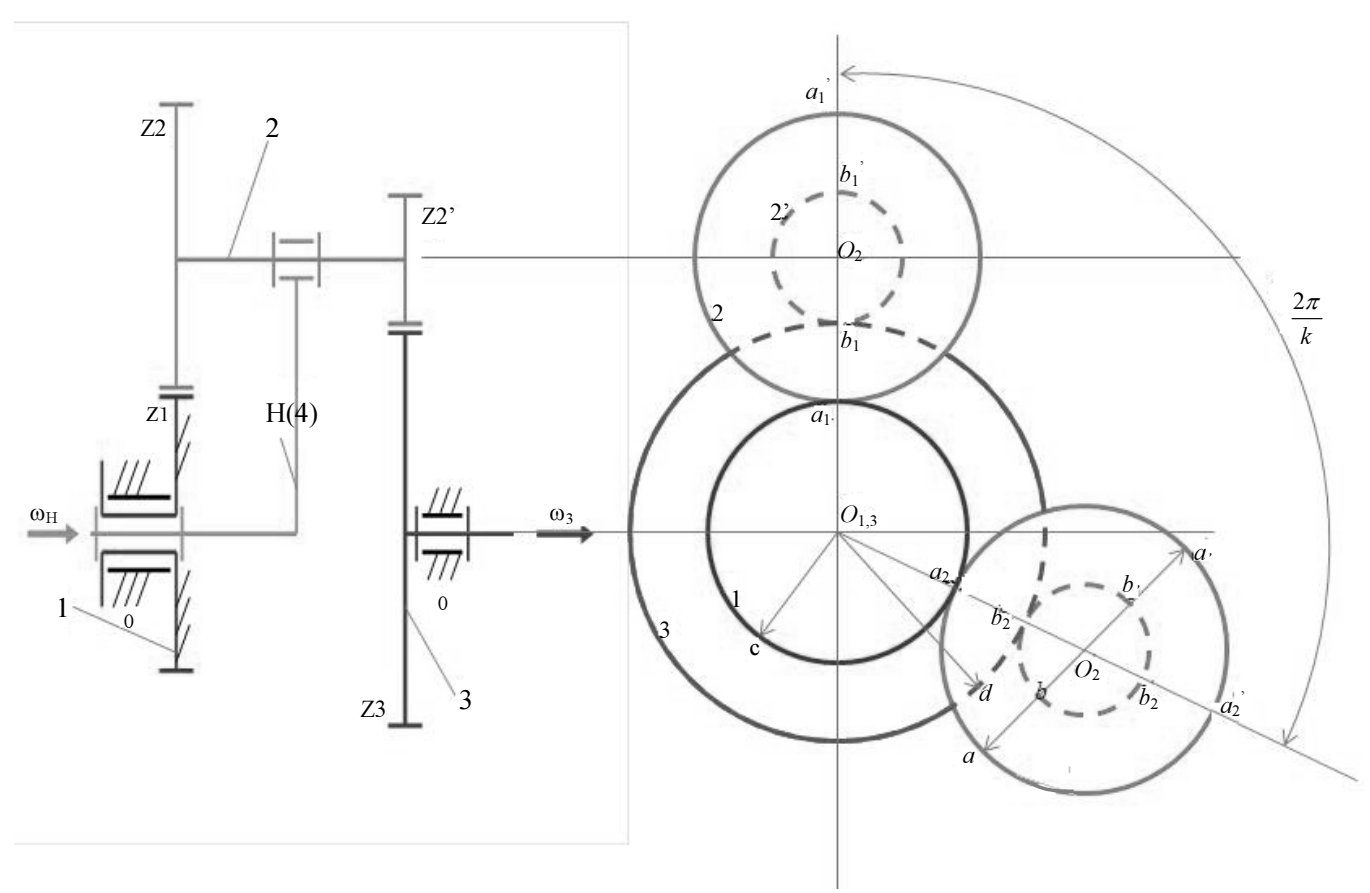

Fig. 6: Geometric and kinematics synthesis of a simple planetary mechanism

b) Coaxial condition

For the axes of all wheels to be coaxial, the condition $\mathrm{O}_{1} \mathrm{O}_{2}=\mathrm{O}_{3} \mathrm{O}_{2}$ must be met; which can also be written $r_{1}+$ $r_{2}=r_{3}+r_{2} ;$ or $1 / 2\left(d_{1}+d_{2}=d_{3}+d_{2}\right)$; or $1 / 2\left(m_{1} z_{1}+m_{1} z_{2}=\right.$ $\left.m_{2} z_{3}+m_{2} z_{2}\right)$; if we use the same module at both gears $\left(m_{1}=m_{2}=m\right)$ we obtain the particular form of the coaxial condition (4) expressed in two different ways:

$$
\left\{\begin{array}{l}
z_{1}+z_{2}=z_{3}+z_{2} \\
z_{3}-z_{1}=z_{2}-z_{2}
\end{array}\right.
$$

(c) The condition for achieving a required inputoutput transmission, $i_{H 3}$

It is written in the system (5) the relations already known from the planetary cinematics:

$$
\left\{\begin{array}{l}
i_{H 3}=i_{H 3}^{1}=\frac{1}{i_{3 H}^{1}}=\frac{1}{1-i_{31}^{H}}=\frac{1}{1-\frac{1}{i_{13}^{H}}}=\frac{1}{1-\frac{1}{\frac{z_{2}}{z_{1}} \cdot \frac{z_{3}}{z_{2^{\prime}}}}}=\frac{z_{2} \cdot z_{3}}{z_{2} \cdot z_{3}-z_{1} \cdot z_{2^{\prime}}} \\
\Rightarrow z_{1} \cdot z_{2^{\prime}}=z_{2} \cdot z_{3} \cdot\left(1-\frac{1}{i_{H 3}}\right) \Rightarrow z_{1} \cdot z_{2^{\prime}}=z_{2} \cdot z_{3} \cdot\left(1-i_{3 H}\right)
\end{array}\right.
$$

(d) The condition of (good) neighborhood (of satellite groups)

For the larger satellites belonging to two groups of neighboring satellites not to be touched, it is necessary to introduce the additional, neighboring condition. In the mechanism used (Fig. 6), the larger satellites are 2 compared to 2', so that the neighborhood condition will be checked only at wheels 2 (Fig. 7).
In Fig. 2, the larger satellites (wheels 2), two neighboring groups were forced close to tangency. More cannot be. The two outer circles of the wheels 2 will come in tangent. The wheels (here and the splitting) of the wheels 2 (exaggerated in the figure, precisely for the understanding of the phenomenon) are tangent to the wheel 1 of the center wheel.

OB distance is the sum of the rays $r_{1}+r_{2}$ (distance between axes).

Angle $\pi / k$ (half of the angle $2 \pi / k$ ) is known (because $k$ is specified before synthesis).

It can be calculated immediately with sin function trigonometric, length TB:

$$
\begin{aligned}
& T B=B T=\left(r_{1}+r_{2}\right) \cdot \sin (\pi / k)=m / 2 .\left(z_{1}+z_{2}\right) \\
& \cdot \sin (\pi / k)
\end{aligned}
$$

The outer radius of the wheel 2 is written: $r_{a 2}=m / 2$. $\left(z_{2}+2\right)$

The neighborhood condition results from the inequality of $B T>r_{a 2}$ and is expressed in relations (6):

$$
\left\{\begin{array}{l}
\frac{m}{2} \cdot\left(z_{1}+z_{2}\right) \cdot \sin \frac{\pi}{k}>\frac{m}{2} \cdot\left(z_{2}+2\right) \\
\left(z_{1}+z_{2}\right) \cdot \sin \frac{\pi}{k}>\left(z_{2}+2\right) \\
z_{1}>\frac{z_{2} \cdot\left(1-\sin \frac{\pi}{k}\right)+2}{\sin \frac{\pi}{k}}
\end{array}\right.
$$




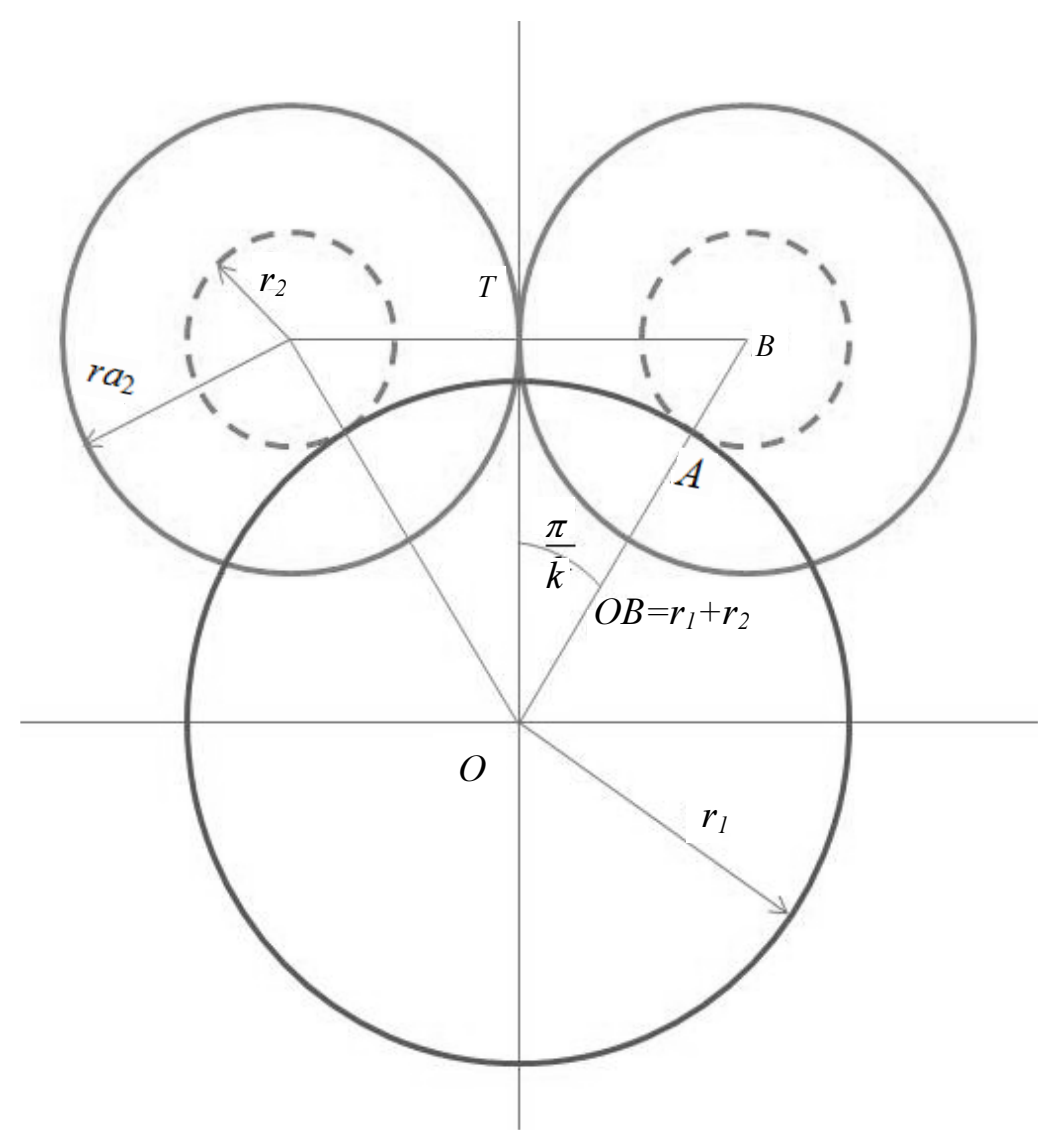

Fig. 7: Neighborhood condition of a simple planetary mechanism

\section{Results and Discussion}

The computational relations compiled for all four conditions are recapitulated in the system (7):

$$
\left\{\begin{array}{l}
z_{3}-z_{1}=z_{2}-z_{2^{\prime}} \\
z_{1} \cdot z_{2^{\prime}}=\left(1-i_{3 H}\right) \cdot z_{2} \cdot z_{3} \Rightarrow z_{1} \cdot z_{2^{\prime}}=C \cdot z_{2} \cdot z_{3} ; C=1-i_{3 H} \\
z_{1}=k \cdot N_{1} ; z_{3}=k \cdot N_{2} ; z_{3}-z_{1}=k \cdot N_{3} ; z_{3}+z_{1}=k \cdot N_{4} \\
z_{1}>\frac{z_{2} \cdot\left(1-\sin \frac{\pi}{k}\right)+2}{\sin \frac{\pi}{k}}
\end{array}\right.
$$

Way of working:

- Write the Initial Calculation Relationships (8):

$$
\left\{\begin{array}{l}
z_{2}=z_{1} \cdot \frac{z_{3}-z_{1}}{z_{1}-C \cdot z_{3}} \\
z_{2^{\prime}}=C \cdot z_{3} \cdot \frac{z_{3}-z_{1}}{z_{1}-C \cdot z_{3}}
\end{array}\right.
$$

- We give: $k$ and $i_{H 3}$. Calculate immediately: $i_{3 H}$ and $C$

- $\quad z_{1}$ and $z_{3}$ are chosen so that both are greater than or equal to $z_{\min }$ to automatically observe the avoidance condition $\left(z_{\min }=18\right)$, but also the four simultaneous engagement conditions

- Calculate with (8) $z_{2}$ and $z_{2}$. If both are exactly integer numbers, check the neighborhood condition and if that's OK, stop the process

If $z_{2}$ and/or $z_{2}$ are not exactly integer numbers, then they are rounded to the nearest natural value, using the relation (9) to obtain $z_{2}^{*}, z_{2^{\prime}}^{*}$, with which the required transmission ratio $i_{H 3}^{*}$ is recalculated.

$$
i_{H 3}^{*}=\frac{z_{2}^{*} \cdot z_{3}}{z_{2}^{*} \cdot z_{3}-z_{1} \cdot z_{2}^{*}}
$$

If $i_{H 3}^{*}$ it does not exceed $i_{H 3}$ plus or minus about six or seven percent then the calculations are $\mathrm{OK}$ and the synthesis ends; Otherwise, the whole process is resumed at the end with another pair of teeth $z_{1}, z_{3}$.

The data gathered at the output will be: 


$$
i_{H 3}^{*}, z_{1}, z_{3}, z_{2}^{*}, z_{2}^{*}
$$

\section{Conclusion}

The simple planetary mechanism is geometrically synthesized by determining the four tooth numbers of the component wheels.

There are four main conditions that if not obeyed the mechanism will be blocked, will work with interruptions, or will not work at all:

a) The first condition in the geometric-kinematic synthesis of a simple planetary is the uniform loading of satellites (satellite groups) (or the simultaneous engagement condition)

b) The coaxiality condition is the second one to be observed, otherwise, the mechanism is inoperative

c) The condition for achieving a required input-output transmission ratio is the third major condition, which results from the necessity of conceiving the mechanism according to the required operation

d) The fourth imposed condition is that of (good) neighboring (of the satellite groups), which is necessary for the larger satellites belonging to two groups of neighboring satellites not to be touched, which is why it is necessary to introduce the additional condition, neighborhood

\section{Acknowledgement}

This text was acknowledged and appreciated by Dr. Veturia CHIROIU Honorific member of Technical Sciences Academy of Romania (ASTR) PhD supervisor in Mechanical Engineering.

\section{Funding Information}

Research contract: Contract number 36-5-4D/1986 from 24IV1985, beneficiary CNST RO (Romanian National Center for Science and Technology) Improving dynamic mechanisms internal combustion engines. All these matters are copyrighted. Copyrights: 548-cgiywDssin, from: 22-04-2010, 08:48:48.

\section{Author's Contributions}

All the authors contributed equally to prepare, develop and carry out this manuscript.

\section{Ethics}

This article is original and contains unpublished material. Authors declare that are not ethical issues and no conflict of interest that may arise after the publication of this manuscript.

\section{References}

Antonescu, P., 2000. Mechanisms and Handlers. 1st Edn., Printech Publishing House, Bucharest.

Antonescu, P. and F. Petrescu, 1985. Analytical method of synthesis of cam mechanism and flat stick. Proceedings of the 4th International Symposium on Mechanism Theory and Practice, (TPM' 85), Bucharest.

Antonescu, P. and F. Petrescu, 1989. Contributions to cinetoelastodynamic analysis of distribution mechanisms. Bucharest.

Antonescu, P., M. Oprean and F. Petrescu, 1985a. Contributions to the synthesis of oscillating cam mechanism and oscillating flat stick. Proceedings of the 4th International Symposium on Theory and Practice of Mechanisms, (TPM' 85), Bucharest.

Antonescu, P., M. Oprean and F. Petrescu, 1985b. At the projection of the oscillante cams, there are mechanisms and distribution variables. Proceedings of the 5th Conference for Engines, Automobiles, Tractors and Agricultural Machines, I-Engines and Automobiles, (AMA' 85), Brasov.

Antonescu, P., M. Oprean and F. Petrescu, 1986. Projection of the profile of the rotating camshaft acting on the oscillating plate with disengagement. Proceedings of the 3rd National Computer Assisted Designing Symposium in Mechanisms and Machine Bodies, (MOM' 86), Brasov.

Antonescu, P., M. Oprean and F. Petrescu, 1987. Dynamic analysis of the cam distribution mechanisms. Proceedings of the 7th National Symposium of Industrial Robots and Spatial Mechanisms, (IMS' 87), Bucharest,

Antonescu, P., M. Oprean and F. Petrescu, 1988. Analytical synthesis of Kurz profile, rotating flat cam cam. Machine Build. Rev. Bucharest.

Antonescu, P., F. Petrescu and O. Antonescu, 1994. Contributions to the synthesis of the rotating cam mechanism and the tip of the balancing tip. Brasov.

Antonescu, P., F. Petrescu and D. Antonescu, 1997. Geometrical synthesis of the rotary cam and balance tappet mechanism. Bucharest.

Antonescu, P., F. Petrescu and O. Antonescu, 2000a. Contributions to the synthesis of the rotary disc-cam profile. Proceedings of the 8th International Conference on Theory of Machines and Mechanisms, (TMM' 00), Liberec, Czech Republic, pp: 51-56.

Antonescu, P., F. Petrescu and O. Antonescu, 2000b. Synthesis of the rotary cam profile with balance follower. Proceedings of the 8th Symposium on Mechanisms and Mechanical Transmissions, (MMT'00), Timişoara, pp: 39-44. 
Antonescu, P., F. Petrescu and O. Antonescu, 2001. Contributions to the synthesis of mechanisms with rotary disc-cam. Proceedings of the 8th IFToMM International Symposium on Theory of Machines and Mechanisms, (TMM' 01), Bucharest, ROMANIA, pp: 31-36.

Aversa, R., R.V. Petrescu, A. Apicella and F.I.T. Petrescu, 2017a. Nano-diamond hybrid materials for structural biomedical application. Am. J. Biochem. Biotechnol., 13: 34-41. DOI: 10.3844/ajbbsp.2017.34.41

Aversa, R., R.V. Petrescu, B. Akash, R.B. Bucinell and J.M. Corchado et al., 2017b. Kinematics and forces to a new model forging manipulator. Am. J. Applied Sci., 14: 60-80. DOI: 10.3844/ajassp.2017.60.80

Aversa, R., R.V. Petrescu, A. Apicella, F.I.T. Petrescu and J.K. Calautit et al., 2017c. Something about the V engines design. Am. J. Applied Sci., 14: 34-52. DOI: 10.3844/ajassp.2017.34.52

Aversa, R., D. Parcesepe, R.V. Petrescu, F. Berto and G. Chen et al., 2017d. Processability of bulk metallic glasses. Am. J. Applied Sci., 14: 294-301. DOI: 10.3844/ajassp.2017.294.301

Aversa, R., R.V. Petrescu, A. Apicella and F.I.T. Petrescu, 2017e. Modern transportation and photovoltaic energy for urban ecotourism. Transylvanian Rev. Admin. Sci., 13: 5-20. DOI: $10.24193 /$ tras.SI2017.1

Aversa, R., F.I.T. Petrescu, R.V. Petrescu and A. Apicella, 2016a. Biomimetic FEA bone modeling for customized hybrid biological prostheses development. Am. J. Applied Sci., 13: 1060-1067. DOI: 10.3844/ajassp.2016.1060.1067

Aversa, R., D. Parcesepe, R.V. Petrescu, G. Chen and F.I.T. Petrescu et al., 2016b. Glassy amorphous metal injection molded induced morphological defects. Am. J. Applied Sci., 13: 1476-1482.

DOI: 10.3844 /ajassp.2016.1476.1482

Aversa, R., R.V. Petrescu, F.I.T. Petrescu and A. Apicella, 2016c. Smart-factory: Optimization and process control of composite centrifuged pipes. Am. J. Applied Sci., 13: 1330-1341. DOI: 10.3844 /ajassp.2016.1330.1341

Aversa, R., F. Tamburrino, R.V. Petrescu, F.I.T. Petrescu and M. Artur et al., 2016d. Biomechanically inspired shape memory effect machines driven by muscle like acting NiTi alloys. Am. J. Applied Sci., 13: 1264-1271.

DOI: 10.3844/ajassp.2016.1264.1271

Cao, W., H. Ding, Z. Bin and C. Ziming, 2013. New structural representation and digital-analysis platform for symmetrical parallel mechanisms. Int. J. Adv. Robot. Syst. DOI: 10.5772/56380

Cataldo, R., 2006. Overview of planetary power system options for education. ITEA Human Exploration Project Authors, 2006, at Glenn Research Center. Brooke Park, OH.
Cayley George, From Wikipedia. The free encyclopedia. https://en.wikipedia.org/wiki/George_Cayley

Chen, J. and R.J. Patton, 1999. Robust Model-Based Fault Diagnosis for Dynamic Systems. 1st Edn., Kluwer Academic Publisher, Boston.

Clément, A., From Wikipedia. The free encyclopedia. https://en.wikipedia.org/wiki/Cl\%C3\%A9ment Ader

Coandă-1910, From Wikipedia. The free encyclopedia. https://en.wikipedia.org/wiki/Coand\%C4\%83-1910

Comănescu, A., D. Comănescu, I. Dugăeşescu and A. Boureci, 2010. The Basics of Modeling Mechanisms. 1st Edn., Politehnica Press Publishing House, Bucharest, ISBN-10: 978-606-515-115-4, pp: 274.

Crickmore, P.F., 1997. Lockheed's blackbirds-A-12, YF-12 and SR-71A. Wings Fame, 8: 30-93.

Donald, D., 2003. Lockheed's blackbirds: A-12, YF-12 and SR-71". Black Jets. AIRtime.

Dong, H., N. Giakoumidis, N. Figueroa and N. Mavridis, 2013. Approaching behaviour monitor and vibration indication in developing a General Moving Object Alarm System (GMOAS). Int. J. Adv. Robot. Syst. DOI: $10.5772 / 56586$

Droste, J., 1915. On the field of a single centre in Einstein's theory of gravitation. Koninklijke Nederlandsche Akademie van Wetenschappen Proc., 17: 998-1011.

De Melo, L.F., S.F. Rosário and J.M., Rosário, 2012. Mobile robot navigation modelling, control and applications. Int. Rev. Modell. Simulat., 5: 1059-1068.

Fernandez, V., F. Luis, L.F. Penin, J. Araujo, and A. Caramagno, 2005. Modeling and FDI specification of a RLV Re-entry for robust estimation of sensor and actuator faults. Proceedings of the AIAA Guidance, Navigation and Control Conference and Exhibit, Aug. 15-18, San Francisco.

DOI: $10.2514 / 6.2005-6254$

Finkelstein, D., 1958. Past-future asymmetry of the gravitational field of a point particle. Phys. Rev., 110: 965-967.

Fonod, R., D. Henry, C. Charbonnel and E. Bornschlegl, 2015. Position and attitude model-based thruster fault diagnosis: A comparison study. J. Guidance Control Dynam., 38: 1012-1026. DOI: $10.2514 / 1 . G 000309$

Frățilă, G., M. Frățilă and S. Samoilă, 2011. Automobiles, Construction, Exploitation, Reparation. 10th Edn., EDP, Bucharest, ISBN 978973-30-2857-4.

Garcia, E., M.A. Jimenez, P.G. De Santos and M. Armada, 2007. The evolution of robotics research. IEEE Robot. Autom. Magaz., 14: 90-103. DOI: 10.1109/MRA.2007.339608

Garcia-Murillo, M., J. Gallardo-Alvarado and E. Castillo-Castaneda, 2013. Finding the generalized forces of a series-parallel manipulator. IJARS. DOI: $10.5772 / 53824$ 
Goddard, 1916. Rocket apparatus patent December 15, 1916, Smithsonian Institution Archives.

Goodall, J., 2003. Lockheed's SR-71 "Blackbird" Family. 1st Edn., Aerofax/Midland Publishing, Hinckley, UK, ISBN-10: 1-85780-138-5.

Gorder, P.F., 2015. What's on the surface of a black hole? Not a "firewall"-and the nature of the universe depends on it, a physicist explains. https://news.osu.edu/news/2015/06/16/fuzzyhologram/

Graham, R.H., 2002. SR-71 Blackbird: Stories, Tales and Legends. 1st Edn., Zenith Imprint, North Branch, Minnesota, ISBN-10: 1610607503.

Gruener, J.E., 2006. Lunar exploration (Presentation to ITEA Human Exploration Project Authors, November 2006, at Johnson Space Center). Houston, TX.

Gunston, B., 2010. Airbus: The Complete Story. 1st Edn., Haynes Publishing UK, Sparkford, ISBN-10: 1844255859, pp: 288.

He, B., Z. Wang, Q. Li, H. Xie and R. Shen, 2013. An analytic method for the kinematics and dynamics of a multiple-backbone continuum robot. IJARS. DOI: $10.5772 / 54051$

Hewish, A., 1970. Pulsars. Ann. Rev. Astronomy Astrophys., 8: 265-296.

Jenkins, D.R., 2001. Lockheed Secret Projects: Inside the Skunk Works. 1st Edn., MBI Publishing Company, Zenith Imprint, St. Paul, Minnesota, ISBN-10: 1610607287.

Kaufman, H.R., 1959. Installations at NASA Glenn.

Laming, T., 2000. Airbus A320. 1st Edn., Zenith Press.

Landis, T.R. and D.R. Jenkins, 2005. Lockheed Blackbirds. 1st Edn., Specialty Press, North Branch, ISBN-10: 1580070868, pp: 104.

Lee, B.J., 2013. Geometrical derivation of differential kinematics to calibrate model parameters of flexible manipulator. Int. J. Adv. Robot. Syst.

DOI: $10.5772 / 55592$

Lin, W., B. Li, X. Yang and D. Zhang, 2013. Modelling and control of inverse dynamics for a 5-DOF parallel kinematic polishing machine. Int. J. Adv. Robot. Syst. DOI: 10.5772/54966

List the first flights, From Wikipedia, free encyclopedia. https://ro.wikipedia.org/wiki/List\%C4\%83_cu_prim ele_zboruri

Liu, H., W. Zhou, X. Lai and S. Zhu, 2013. An efficient inverse kinematic algorithm for a PUMA560structured robot manipulator. IJARS. DOI: $10.5772 / 56403$

Lu, P., L. Van Eykeren, E. van Kampen and Q.P. Chu, 2015. Selective-reinitialization multiple-model adaptive estimation for fault detection and diagnosis. J. Guidance Control Dynam., 38: 1409-1424. DOI: $10.2514 / 1 . G 000587$
Lu, P., L. Van Eykeren, E. van Kampen, C.C. de Visser and Q.P. Chu, 2016. Adaptive three-step kalman filter for air data sensor fault detection and diagnosis. J. Guidance Control Dynam., 39: 590-604.

DOI: $10.2514 / 1 . G 001313$

Michell, J., 1784. On the means of discovering the distance, magnitude and c. of the fixed stars, in consequence of the diminution of the velocity of their light, in case such a diminution should be found to take place in any of them and such other data should be procured from observations, as would be farther necessary for that purpose. Philosophical Trans. Royal Society, 74: 35-57.

Mirsayar, M.M., V.A. Joneidi, R.V. Petrescu, F.I.T. Petrescu and F. Berto, 2017. Extended MTSN criterion for fracture analysis of soda lime glass. Eng. Fracture Mechan., 178: 50-59.

DOI: $10.1016 /$ j.engfracmech.2017.04.018

Murray, K., A. Marcos and L.F. Penin, 2010. Development and testing of a GNC-FDI filter for a reusable launch vehicle during ascent. Proceedings of the AIAA Guidance, Navigation and Control Conference, Aug. 2-5, Toronto, Ontario Canada. DOI: $10.2514 / 6.2010-8195$

Norris, G., 2010. Airbus A380: Superjumbo of the 21st Century. 1st Edn., Zenith Press.

Oberth, H., 1955. They come from outer space. Fly. Saucer Rev., 1: 12-14.

Oppenheimer, J.R. and G.M. Volkoff, 1939. On massive neutron cores. Phys. Rev., 55: 374-381.

Padula, F. and V. Perdereau, 2013. An on-line path planner for industrial manipulators. Int. J. Adv. Robot. Syst. DOI: 10.5772/55063

Palumbo, R., G. Morani, M. De Stefano Fumo, C. Richiello and M. Di Donato et al., 2012. Concept study of an atmospheric reentry using a winged unmanned space vehicle. Proceedings of the 18th AIAA/3AF International Space Planes and Hypersonic Systems and Technologies Conference, Sept. 24-28, Tours, France. DOI: $10.2514 / 6.2012-5857$.

Patre, P. and S.M. Joshi, 2011. Accommodating sensor bias in MRAC for state tracking. Proceedings of the AIAA Guidance, Navigation and Control Conference, Aug. 8-11, Portland, Oregon. DOI: $10.2514 / 6.2011-6605$

Pelecudi, C., 1967. The Basics of Mechanism Analysis. 1st Edn., Academy of the People's Republic of Romania.

Perumaal, S. and N. Jawahar, 2013. Automated trajectory planner of industrial robot for pick-andplace task. IJARS. DOI: 10.5772/53940

Petrescu, F. and R. Petrescu, 1995a. Contributions to optimization of the polynomial motion laws of the stick from the internal combustion engine distribution mechanism. Bucharest. 
Petrescu, F. and R. Petrescu, 1995b. Contributions to the synthesis of internal combustion engine distribution mechanisms. Bucharest.

Petrescu, F. and R. Petrescu, 1997a. Dynamics of cam mechanisms (exemplified on the classic distribution mechanism). Bucharest.

Petrescu, F. and R. Petrescu, 1997b. Contributions to the synthesis of the distribution mechanisms of internal combustion engines with Cartesian coordinate method. Bucharest.

Petrescu, F. and R. Petrescu, 1997c. Contributions to maximizing polynomial laws for the active stroke of the distribution mechanism from internal combustion engines. Bucharest.

Petrescu, F. and R. Petrescu, 2000a. Synthesis of distribution mechanisms by the rectangular (cartesian) coordinate method. University of Craiova, Craiova.

Petrescu, F. and R. Petrescu, 2000b. The design (synthesis) of cams using the polar coordinate method (the triangle method). University of Craiova, Craiova.

Petrescu, F. and R. Petrescu, 2002a. Motion laws for cams. Proceedings of the 7 th National Symposium with International Participation Computer Assisted Design, (PAC' 02), Braşov, pp: 321-326.

Petrescu, F. and R. Petrescu, 2002b. Camshaft dynamics elements. Proceedings of the 7th National Symposium with International Participation Computer Assisted Design, (PAC' 02), Braşov, pp: 327-332.

Petrescu, F. and R. Petrescu, 2003. Some elements regarding the improvement of the engine design. Proceedings of the 8th National Symposium, Descriptive Geometry, Technical Graphics and Design, (GTD’ 03), Braşov, pp: 353-358.

Petrescu, F. and R. Petrescu, 2005a. The cam design for a better efficiency. Proceedings of the International Conference on Engineering Graphics and Design, (EGD' 05), Bucharest, pp: 245-248.

Petrescu, F. and R. Petrescu, 2005b. Contributions at the dynamics of cams. Proceedings of the 9th IFToMM International Symposium on Theory of Machines and Mechanisms, (TMM' 05), Bucharest, Romania, pp: 123-128.

Petrescu, F. and R. Petrescu, 2005c. Determining the dynamic efficiency of cams. Proceedings of the 9th IFToMM International Symposium on Theory of Machines and Mechanisms, (TMM' 05), Bucharest, Romania, pp: 129-134.

Petrescu, F. and R. Petrescu, 2005d. An original internal combustion engine. Proceedings of the 9th IFToMM International Symposium on Theory of Machines and Mechanisms, (TMM' 05), Bucharest, Romania, pp: 135-140.

Petrescu, F. and R. Petrescu, 2005e. Determining the mechanical efficiency of Otto engine's mechanism. Proceedings of the 9th IFToMM International Symposium on Theory of Machines and Mechanisms, (TMM' 05), Bucharest, Romania, pp: 141-146.
Petrescu, F.I. and R.V. Petrescu, 2013. Cinematics of the 3R Dyad. Engevista, 15: 118-124.

Petrescu, F.I.T. and R.V. Petrescu, 2012a. The Aviation History. 1st Edn., Books On Demand, ISBN-13: 978-3848230778.

Petrescu, F.I. and R.V. Petrescu, 2012b. MecatronicaSisteme Seriale si Paralele. 1st Edn., Create Space Publisher, USA, ISBN-10: 978-1-4750-6613-5, pp: 128.

Petrescu, F.I. and R.V. Petrescu, 2011. Mechanical Systems, Serial and Parallel-Course (in Romanian). LULU Publisher, London, UK, ISBN-10: 978-1-4466-0039-9, pp: 124.

Petrescu, F.I. and R.V. Petrescu, 2016a. Parallel moving mechanical systems kinematics. ENGEVISTA, 18: 455-491.

Petrescu, F.I. and R.V. Petrescu, 2016b. Direct and inverse kinematics to the Anthropomorphic Robots. ENGEVISTA, 18: 109-124.

Petrescu, F. and R. Petrescu, 2016c. An otto engine dynamic model. IJM\&P, 7: 038-048.

Petrescu, F.I. and R.V. Petrescu, 2016d. Otto motor dynamics. GEINTEC, 6: 3392-3406.

Petrescu, F.I. and R.V. Petrescu, 2016e. Dynamic cinematic to a structure 2R. GEINTEC, 6: 3143-3154.

Petrescu, F.I., B. Grecu, A. Comanescu and R.V. Petrescu, 2009. Some mechanical design elements. Proceeding of the International Conference on Computational Mechanics and Virtual Engineering, (MEC' 09), Braşov, pp: 520-525.

Petrescu, R.V., R. Aversa, A. Apicella, M.M. Mirsayar and F.I.T. Petrescu, 2016a. About the gear efficiency to a simple planetary train. Am. J. Applied Sci., 13: 1428-1436. DOI: 10.3844 /ajassp.2016.1428.1436

Petrescu, R.V., R. Aversa, A. Apicella, S. Li and G. Chen et al., 2016b. Something about electron dimension. Am. J. Applied Sci., 13: 1272-1276. DOI: 10.3844/ajassp.2016.1272.1276

Petrescu, F.I.T., A. Apicella, R. Aversa, R.V. Petrescu and J.K. Calautit et al., 2016c. Something about the mechanical moment of inertia. Am. J. Applied Sci., 13: $1085-1090$. DOI: 10.3844 /ajassp.2016.1085.1090

Petrescu, R.V., R. Aversa, A. Apicella, F. Berto and S. Li et al., 2016d. Ecosphere protection through green energy. Am. J. Applied Sci., 13: 1027-1032. DOI: 10.3844/ajassp.2016.1027.1032

Petrescu, F.I.T., A. Apicella, R.V. Petrescu, S.P. Kozaitis and R.B. Bucinell et al., 2016e. Environmental protection through nuclear energy. Am. J. Applied Sci., 13: 941-946. DOI: 10.3844 /ajassp.2016.941.946

Petrescu, F.I.T. and J.K. Calautit, 2016a. About nano fusion and dynamic fusion. Am. J. Applied Sci., 13: 261-266. DOI: 10.3844/ajassp.2016.261.266 
Petrescu, F.I.T. and J.K. Calautit, 2016b. About the light dimensions. Am. J. Applied Sci., 13: 321-325. DOI: 10.3844/ajassp.2016.321.325

Petrescu, R.V., R. Aversa, B. Akash, R. Bucinell and J. Corchado et al., 2017a. Modern propulsions for aerospace-a review. J. Aircraft Spacecraft Technol., 1: 1-8. DOI: $10.3844 /$ jastsp.2017.1.8

Petrescu, R.V., R. Aversa, B. Akash, R. Bucinell and J. Corchado et al., 2017b. Modern propulsions for aerospace-part II. J. Aircraft Spacecraft Technol., 1: 9-17. DOI: $10.3844 /$ jastsp.2017.9.17

Petrescu, R.V., R. Aversa, B. Akash, R. Bucinell and J. Corchado et al., 2017c. History of aviation-a short review. J. Aircraft Spacecraft Technol., 1: 30-49. DOI: 10.3844 /jastsp.2017.30.49

Petrescu, R.V., R. Aversa, B. Akash, R. Bucinell and J. Corchado et al., 2017d. Lockheed martin-a short review. J. Aircraft Spacecraft Technol., 1: 50-68. DOI: 10.3844 /jastsp.2017.50.68

Petrescu, R.V., R. Aversa, B. Akash, J. Corchado and F. Berto et al., 2017e. Our universe. J. Aircraft Spacecraft Technol., 1: 69-79. DOI: 10.3844/jastsp.2017.69.79

Petrescu, R.V., R. Aversa, B. Akash, J. Corchado and F. Berto et al., 2017f. What is a UFO? J. Aircraft Spacecraft Technol., 1: 80-90. DOI: 10.3844 /jastsp.2017.80.90

Petrescu, R.V., R. Aversa, B. Akash, J. Corchado and F. Berto et al., 2017g. About bell helicopter FCX-001 concept aircraft-a short review. J. Aircraft Spacecraft Technol., 1: 91-96. DOI: $10.3844 /$ jastsp.2017.91.96

Petrescu, R.V., R. Aversa, B. Akash, J. Corchado and F. Berto et al., 2017h. Home at airbus. J. Aircraft Spacecraft Technol., 1: 97-118. DOI: 10.3844 jastsp.2017.97.118

Petrescu, R.V., R. Aversa, B. Akash, J. Corchado and F. Berto et al., 2017i. Airlander. J. Aircraft Spacecraft Technol., 1: 119-148.

DOI: $10.3844 /$ jastsp.2017.119.148

Petrescu, R.V., R. Aversa, B. Akash, J. Corchado and F. Berto et al., 2017j. When boeing is dreaming-a review. J. Aircraft Spacecraft Technol., 1: 149-161. DOI: $10.3844 /$ jastsp.2017.149.161

Petrescu, R.V., R. Aversa, B. Akash, J. Corchado and F. Berto et al., 2017k. About Northrop Grumman. J. Aircraft Spacecraft Technol., 1: 162-185. DOI: $10.3844 /$ jastsp.2017.162.185

Petrescu, R.V., R. Aversa, B. Akash, J. Corchado and F. Berto et al., 20171. Some special aircraft. J. Aircraft Spacecraft Technol., 1: 186-203. DOI: $10.3844 /$ jastsp.2017.186.203

Petrescu, R.V., R. Aversa, B. Akash, J. Corchado and F. Berto et al., 2017m. About helicopters. J. Aircraft Spacecraft Technol., 1: 204-223.

DOI: $10.3844 /$ jastsp.2017.204.223
Petrescu, R.V., R. Aversa, B. Akash, F. Berto and A. Apicella et al., 2017n. The modern flight. J. Aircraft Spacecraft Technol., 1: 224-233.

DOI: 10.3844 /jastsp.2017.224.233

Petrescu, R.V., R. Aversa, B. Akash, F. Berto and A. Apicella et al., 2017o. Sustainable energy for aerospace vessels. J. Aircraft Spacecraft Technol., 1: 234-240. DOI: 10.3844/jastsp.2017.234.240

Petrescu, R.V., R. Aversa, B. Akash, F. Berto and A. Apicella et al., 2017p. Unmanned helicopters. J. Aircraft Spacecraft Technol., 1: 241-248. DOI: 10.3844 /jastsp.2017.241.248

Petrescu, R.V., R. Aversa, B. Akash, F. Berto and A. Apicella et al., 2017q. Project HARP. J. Aircraft Spacecraft Technol., 1: 249-257.

DOI: 10.3844 /jastsp.2017.249.257

Petrescu, R.V., R. Aversa, B. Akash, F. Berto and A. Apicella et al., 2017r. Presentation of romanian engineers who contributed to the development of global aeronautics-part I. J. Aircraft Spacecraft Technol., 1: 258-271.

DOI: 10.3844 /jastsp.2017.258.271

Petrescu, R.V., R. Aversa, B. Akash, F. Berto and A. Apicella et al., 2017s. A first-class ticket to the planet mars, please. J. Aircraft Spacecraft Technol., 1: 272-281. DOI: 10.3844/jastsp.2017.272.281

Petrescu, R.V., R. Aversa, B. Akash, F. Berto and A. Apicella et al., 2017t. Forces of a 3R robot. J. Mechatron. Robot., 1: 1-14. DOI: $10.3844 /$ jmrsp.2017.1.14

Petrescu, R.V., R. Aversa, B. Akash, F. Berto and A. Apicella et al., 2017u. Direct geometry and cinematic to the MP-3R systems. J. Mechatron. Robot., 1: 15-23. DOI: 10.3844/jmrsp.2017.15.23

Petrescu, R.V., R. Aversa, B. Akash, F. Berto and A. Apicella et al., 2017v. Dynamic elements at MP3R. J. Mechatron. Robot., 1: 24-37. DOI: $10.3844 / j m r s p .2017 .24 .37$

Petrescu, R.V., R. Aversa, B. Akash, F. Berto and A. Apicella et al., 2017w. Geometry and direct kinematics to MP3R with $4 \times 4$ operators. J. Mechatron. Robot., 1: 38-46. DOI: $10.3844 /$ jmrsp.2017.38.46

Petrescu, R.V., R. Aversa, A. Apicella, M.M. Mirsayar and S. Kozaitis et al., 2017x. Current stage in the field of mechanisms with gears and rods. J. Mechatron. Robot., 1: 47-57. DOI: 10.3844 jmrsp.2017.47.57

Petrescu, R.V., R. Aversa, A. Apicella, M.M. Mirsayar and S. Kozaitis et al., 2017y. Geometry and inverse kinematic at the MP3R mobile systems. J. Mechatron. Robot., 1: 58-65. DOI: $10.3844 / j m r s p .2017 .58 .65$ 
Petrescu, R.V., R. Aversa, A. Apicella, M.M. Mirsayar and S. Kozaitis et al., 2017z. Synthesis of optimal trajectories with functions control at the level of the kinematic drive couplings. J. Mechatron. Robot., 1: 66-74. DOI: $10.3844 /$ jmrsp.2017.66.74

Petrescu, R.V., R. Aversa, A. Apicella, M.M. Mirsayar and S. Kozaitis et al., 2017aa. The inverse kinematics of the plane system 2-3 in a mechatronic MP2R system, by a trigonometric method. J. Mechatron. Robot., 1: 75-87. DOI: 10.3844/jmrsp.2017.75.87

Petrescu, R.V., R. Aversa, A. Apicella, M.M. Mirsayar and S. Kozaitis et al., 2017ab. Serial, anthropomorphic, spatial, mechatronic systems can be studied more simply in a plan. J. Mechatron. Robot., 1: 88-97. DOI: 10.3844/jmrsp.2017.88.97

Petrescu, R.V., R. Aversa, A. Apicella, M.M. Mirsayar and S. Kozaitis et al., 2017ac. Analysis and synthesis of mechanisms with bars and gears used in robots and manipulators. J. Mechatron. Robot., 1: 98-108. DOI: 10.3844/jmrsp.2017.98.108

Petrescu, R.V., R. Aversa, A. Apicella, M.M. Mirsayar and S. Kozaitis et al., 2017ad. Speeds and accelerations in direct kinematics to the MP3R systems. J. Mechatron. Robot., 1: 109-117. DOI: $10.3844 /$ jmrsp.2017.109.117

Petrescu, R.V., R. Aversa, A. Apicella, M.M. Mirsayar and S. Kozaitis et al., 2017ae. Geometry and determining the positions of a plan transporter manipulator. J. Mechatron. Robot., 1: 118-126. DOI: $10.3844 /$ jmrsp.2017.118.126

Reddy, P., K.V. Shihabudheen and J. Jacob, 2012. Precise non linear modeling of flexible link flexible joint manipulator. IReMoS, 5: 1368-1374.

Sevil, H.E. and A. Dogan, 2015. Fault diagnosis in air data sensors for receiver aircraft in aerial refueling. J. Guidance Control Dynam., 38: 1959-1975. DOI: 10.2514/1.G000527

Sherson, J.F., H. Krauter, R.K. Olsson, B. Julsgaard and K. Hammerer et al., 2006. Quantum teleportation between light and matter. Nature, 443: 557-560. DOI: 10.1038 /nature05136
Sun, J. Z. and S.M. Joshi, 2009. An indirect adaptive control scheme in the presence of actuator and sensor failures. Proceedings of the AIAA Guidance, Navigation and Control Conference, Chicago, Illinois, Aug. 10-13, Chicago, Illinois.

DOI: $10.2514 / 6.2009-5740$

Tabaković, S., M. Zeljković, R. Gatalo and A. $\mathrm{Z} \square$ ivković, 2013. Program suite for conceptual designing of parallel mechanism-based robots and machine tools. Int. J. Adv. Robot Syst. DOI: $10.5772 / 56633$

Tang, X., D. Sun and Z. Shao, 2013. The structure and dimensional design of a reconfigurable PKM. IJARS. DOI: $10.5772 / 54696$

Tong, G., J. Gu and W. Xie, 2013. Virtual entity-based rapid prototype for design and simulation of humanoid robots. Int. J. Adv. Robot. Syst. DOI: $10.5772 / 55936$

Venkataraman, G., 1992. Chandrasekhar and his Limit. 1st Edn., Universities Press, ISBN-10: 817371035X, pp: 89.

Wang, K., M. Luo, T. Mei, J. Zhao and Y. Cao, 2013. Dynamics analysis of a three-DOF planar serialparallel mechanism for active dynamic balancing with respect to a given trajectory. Int. J. Adv. Robotic Syst. DOI: 10.5772/54201

Ward, T.A., 2010. Aerospace Propulsion Systems. 1st Edn., Wiley publisher. ISBN-13: 9780470824979

Williams, D.R., 1995. Saturnian satellite fact sheet. NASA.

https://nssdc.gsfc.nasa.gov/planetary/factsheet/satur niansatfact.html

Wen, S., J. Zhu, X. Li, A. Rad and X. Chen, 2012. Endpoint contact force control with quantitative feedback theory for mobile robots. IJARS.

DOI: $10.5772 / 53742$ 